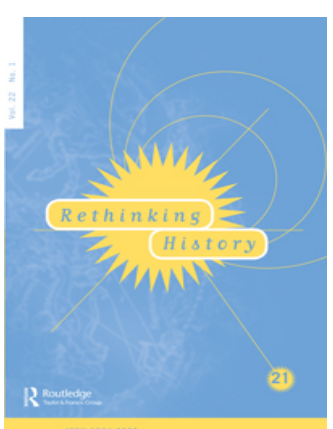

Rethinking History

The Journal of Theory and Practice

\title{
Aftermaths of the dawn of experience: on the impact of Ankersmit's sublime historical experience
}

Jonathan Menezes

To cite this article: Jonathan Menezes (2018) Aftermaths of the dawn of experience: on the impact of Ankersmit's sublime historical experience, Rethinking History, 22:1, 44-64, DOI: 10.1080/13642529.2017.1423009

To link to this article: https://doi.org/10.1080/13642529.2017.1423009

曲 Published online: 11 Jan 2018.

Submit your article to this journal $\llbracket$

Џ Article views: 239

View Crossmark data $\complement$ 


\title{
Aftermaths of the dawn of experience: on the impact of Ankersmit's sublime historical experience
}

\author{
Jonathan Menezes ${ }^{a, b}$
}

${ }^{a}$ South American Theological Faculty, Department of Philosophy, Londrina, Brazil; ${ }^{b}$ Department of History, State University of São Paulo, Brazil

\begin{abstract}
Historical experience is one of the most important topics of Frank Ankersmit's work. As we shall see in this article, 'historical experience' in the Ankersmitean sense is a rare and complex kind of experience, entirely different from the experiences we have in our daily lives, because it presupposes that a historian can be in direct contact with a past that is long gone. But can we really experience the past? How could a historian perform this? As Ankersmit has admitted, this impractical and unusual choice of experience as one of his theoretical guides is controversial, to say the least, especially among scholars strongly oriented by the linguistic turn, narrativism, postmodernism, and so on, because he claims that experience should have priority over language. In this article, the aim is to investigate some of the effects or the aftermaths of what I term 'the dawn of experience' in current theory and philosophy of history. The aim is also to question whether this dawn of experience necessarily means banishing language or representation. In my view, it does not, and experience presupposes a suspension of language, not a complete abandonment of it.
\end{abstract}

\section{ARTICLE HISTORY Received 18 December 2017; Accepted 27 December 2017}

KEYWORDS Historical experience; historical representation; Ankersmit; Huizinga; narrativism; dissociation; suspension of language

\section{Historical experience in the hot seat}

Let me begin with a very thoughtful allegory presented by Hans Kellner in a 2006 essay called 'Ankersmit's Proposal: Let's Keep in Touch', which sheds light on Ankersmit's place in the world of historical theory in recent decades:

Imagine a committee that has sat for many years, discussing policy concerning a certain matter. Despite the inevitable changes of personnel, the substance of the matter is agreed upon, and the basic principles of its operation are recognized - the grammar and syntax of it, as a committee member might say. One senior member of the committee, however, highly respected and active, seems 
to operate outside the consensus of the group. Although his persuasive powers are formidable and his interventions frequent and brilliantly argued, he seems to be working in a parallel world. His comments describe quite a different matter from the familiar one the committee considers. Admired for his knowledge and the extraordinary eruditio of his comments, he remains a bit apart, and a bit frustrated at the discussions. Occasionally he will mutter, 'but time has nothing to do with history,' 'truth has no place in this discussion,' or 'where language is, experience is not,' but the group moves on over the same ground. To engage with his ideas, to follow his suggestions, would entail a nearly total revision of their project, a redefinition of their mission, a trek into unknown territory, a new identity. (Kellner 2006, 85, 86)

Historical experience has been put into the hot seat within discussions in the theory and philosophy of history in the last decade or so. The most important and debated book on the subject has been Frank Ankersmit's Sublime Historical Experience (2005), which for me is the second most important book of his career. As much as his first (and, to me, the most important) book, Narrative Logic (1983), Sublime Historical Experience marked a turning point in the debate. In Narrative Logic, Ankersmit claimed that philosophy of history needed to turn to the linguistic in order to move forward, paying more attention to the 'semantics of the historian's language' (as stated in the book's subtitle) as well as to what happens on the level of the (historical) text, towards which philosophy of history and historiography had remained relatively 'blind' thus far.

In contrast, the discontentment expressed by the 2005 book was provoked by everything (even the part of his own theorizations) that had previously been presented under the linguistic 'umbrella'. For, according to Ankersmit, 'what all these theories have in common is the conviction of the impossibility of a direct access to the past; the past became hidden behind an impenetrable screen of language' (Ankersmit 2016, 352). This was one of the reasons for his interest in the notion of historical experience: 'historical experience or historical sensation (as the Dutch historian Huizinga put it) restores this immediate and direct contact with the past' (Ankersmit 2016, 352).

Such talk of being in touch with or reviving the past by escaping from the constraints of language or - in Nietzsche's terms, and ones much used by Ankersmit - from the prisonhouse of language, was not attractive in a theoretical realm where language not only precedes experience but precedes almost everything. Arguably language - for most of the committee members of Kellner's analogy - did not precede the world ontologically speaking (and I think it is simply misleading to maintain that authors like White, LaCapra or the 'early Ankersmit' were all claiming that 'the world is a text'). But nor could it place us into contact with the 'real world' or the 'real past'. Instead, it created a whole new world, metaphorically speaking, and stood as a condition of possibility for historical knowledge. Hence, as Kellner $(2006,99)$ observed: 'The paths of the philosophy of history were marked, and were explored. All of this was predicated on the sacrifice of historical experience. It looks like a 
paradise lost, a mistaken direction. Ankersmit wants to show us another way' - a forgotten way.

Indeed, (sublime) historical experience arrived on the scene much like an alien or a radical stranger, directing at least part of the debate towards the possibility of an 'outside': the outside to language, to narrative, to representation, and so on and so forth. It also appeared as a farewell, at least for the time being, by aiming to do away with the linguistic transcendentalism of authors such as Rorty and, repeating Ankersmit's words, with all the 'cumbersome products of transcendentalist bureaucracy', such as semiotics, hermeneutics, tropology, deconstructivism, textualism, and so on. All this came as an attempt to 'rescue the past itself from what we speak about it' (Ankersmit 2005, 4), underlined by a provocative ending to the book's second chapter: 'So let us throw open the windows of this narrow and stuffy room that we have been living in for the last fifty years - and let us breathe again the fresh air of the outside world!' (Ankersmit 2005, 106).

Yet this 'breathing again' was something that couldn't come about without some sacrifices, like the momentary sacrifice of language, of context and of oneself. 'Breathing' in this way involves the realization of Ranke's old dream of effacing himself 'to call upon the things, and the powerful forces of the past themselves to speak' (quoted in Ankersmit 2005, 165). While one might object that this contradicts Ankersmit's own judgement of the Rankean exclamation as a 'pathetic' one $(2005,165)$, we should not forget Ranke's aim even if, of course, neither Ankersmit nor anyone else today would believe in this possibility. Narrativism has permanently removed our innocence regarding the (historical) text, as Ankersmit has indeed recognized many times. Thus, to fulfil the historicist dream without compromising this philosophical achievement, one must take an old, forgotten and despised route: the path of historical experience, which I would call the Route 66 of the philosophy of history, the most 'subaltern' of philosophical appeals, to use Craig Ireland's analogy (2004). Even Ankersmit has recently noted that 'experience belongs to the most 'proletarian' of philosophical concepts; it is the prototypical "loser"' (Ankersmit and Menezes 2017, 268).

In taking this deserted route, Ankersmit realized that he needed to discover some 'new talent', and I am thinking here particularly of what he named 'the talent of dissociation' (Ankersmit 2005, 236), which I will take as an illustration of his sublime historical experience. The 'talent of dissociation' has to do with 'being able to momentarily discard from yourself all that you think to be essential to you and to your identity' (Ankersmit 2005, 227). However, he recognized that this might be one of the most counterintuitive abilities since the art of being human is 'the art of association' - 'our identities, all our conceptions of the world, of history and historical writing, for that matter, are all the product of association' (Ankersmit 2005, 228). 
Historical experience, on the other hand, represented a moment of dissociation of our identity - as if we were out of ourselves - and is thus an experience without a subject. In Ankersmit's words: 'We die a partial death at such moments since all that we are is then reduced to just this feeling or experience' (Ankersmit 2005,228 ). The moment of experience is the moment in which you - your context, your language and your identity - disappear from the 'place' where only the experience remains. In one sense, you must lose yourself in order to be in touch with an authentic past. Therefore, thinking back to Ranke: while this may have been a 'pathetic dream' at the level of the historical text, that's not the case on the level of historical experience as envisioned by Ankersmit. ${ }^{1}$ However, the moment when you become aware of having such a direct encounter with some part of the past is when you in fact don't have it anymore. It just slipped through your hands. This is why he associates historical experience with the experience of loss. Sometimes, we become aware of the real value of something only after we lose it. And that is precisely the 'logic' of historical experience for Ankersmit.

In the same manner, that is where history comes into the picture. In Ankersmit's words: 'the entrance of history on the scene is ordinarily associated with a more and less sudden dramatic and/or tragic event that made us regard what was prior to it with a sense of profound loss' (Ankersmit 2012, 181). History or representation comes in when the past or the (dramatic) historical experience goes out - so, historical experience and representation might not be as far apart as they might at first seem. Many historians believe, for example, that contemporary history came into being only with the French Revolution. This is a crucial point for Ankersmit, and one on which he quotes Arthur Danto several times:

And something of the same sort is true for the historical period considered as an entity. It is a period solely from the perspective of the historian, who sees it from without; for those who lived in the period it would be just the way life was lived. And asked, afterwards, what it was like to have lived then, they may answer from the outside, from the historian's perspective. From the inside there is no answer to be given; it was simply the way things were. So when the members of a period can give an answer in terms satisfactory to the historian, the period will have exposed its outward surface and in a sense be over, as a period. (Danto 1981, 207, emphasis mine)

For thinkers like Danto or Ankersmit, there is no purpose in asking 'What is the meaning of life?', for life has no meaning. Life comes first, while meaning comes after. Perhaps we can teleologically speak about 'the purpose of life' - the one you pursue every single day of your miserable existence or the one you believe will take place in the future, or in eternity. But the meaning of life only arises when that life (or part of it) no longer exists. For, life tells us no stories about itself. In Louis Mink's well-known words, 'stories are not lived, but told'. As he emphasizes: 'Life has no beginnings, middles, or ends; there are meetings, but 
the start of an affair belongs to the story we tell ourselves later, and there are partings, but final partings only in the story' (Mink 1970, 557).

Borrowing Danto's words from the passage above, history (as much as historical periods, narrative substances or representations), then, is what you have when you look at life from without (or indirectly, through the sources). The outsiders are those who can have a perspective on the way things were, on how we should label them - 'that was the French Revolution', or 'that was World War I', and so on - or (more importantly) on what kind of sense we can make of them. But the insiders are those who lived through particular times and saw things from within, while, that is, experiencing life. For them, the good and bad, the fortunes and misfortunes of life, were 'simply the way things' were. Hence present life is 'timeless', as Ankersmit $(2005,9)$ would put it. But he would also add:

At some fateful moment, perhaps because of some cataclysmic event to be told from one generation to the other, mankind divided this eternal present (subject) into a past (object) and a future. At that moment, the past was cut off from the present and something we had now lost forever. And the loss is no small thing, for that matter! For it was the loss of the better part of what humanity had been up till then. Is our past not always a much 'bigger' thing than the present? Therefore, all ancient myths about the origins of mankind are stories of the loss of a former paradise, of a phase in which we were, or lived together with the gods. Anyway, this birth-trauma of humanity gave us an objective past - the past as a potential object of historical research. (Ankersmit and Menezes 2017, 270)

Even beyond this, according to Ankersmit, 'it may happen that we'll be captivated later by a longing (like a profound nostalgia) for what was 'timeless' in that past, to that timeless past' (Ankersmit forthcoming, my translation). And this longing for the past, this deep nostalgia that seems, by the way, a part of Ankersmit's own personality, might be the perfect 'mood' for those who are interested in placing themselves in the realm of sublime historical experience. This is what Ankersmit took as a core insight into 'the tragedy of human existence' from his reading of Danto. From this insight, it is much easier to see what role Danto's theorizations had in Ankersmit's account of historical experience; it is precisely through this tragic split between life and history that one may become aware of the loss of a 'former identity' that will define oneself in terms of what one 'no longer' can be (Ankersmit 2007, 190). In response to Ankersmit, Danto said something that is of interest here: 'Personally, I am not given to nostalgia. Especially as a philosopher of art, I am really grateful to have lived through the changes I have experienced, into a period I could never have imagined, say, in the 1960s. But I can sympathize with those to whom historical adjustment has been difficult' (in Ankersmit 2007, 196). This is precisely the case for Ankersmit too, for he never hid his feeling of connectedness to (and nostalgia for) the eighteenth century, or the fact that, for him, it would have been incredible to have had a chance to live in those 'golden times'. This tragic or romantic feature of his personality might be another possible explanation for 
his interest in sublime historical experience; it clearly makes him an 'incurable sentimentalist' (Ankersmit 2012, 183) and existentialist.

It might be objected that there is nothing counterintuitive about simply being inside and living life. But when it comes to the past, how can one be 'inside' or 'look from within'? This is the question that points directly to Ankersmit's Dutch roots and his identification with his countryman Huizinga. In a recent conversation with me (and for the first time since the publication of his book in 2005), Ankersmit elaborated on the Dutch cultural movement behind Huizinga's notion of 'historical sensation', from which he drew inspiration for his idea of 'historical experience':

The term historical sensation ('historische sensatie' in Dutch), as used by Huizinga refers to the literary movement of the so-called 'Tachtigers' (which is Dutch for the movement of the 1880s. One of the main theoreticians of this movement was Karel Johan Lodewijk Alberdingk Thijm (1864-1952) whose pseudonym was Lodewijk van Deyssel). Just as in France at the same time, a number of Dutch poets and novelists in the 1880s began to have their doubts about the literary realism or naturalism of the preceding decades. But whereas the French (think, for example, of Mallarmé) turned toward symbolism, the movement of the $1880 \mathrm{~s}$ moved in exactly the opposite direction. [...] Lodewijk van Deyssel and the movement of the 1880s advocated, as opposed to symbolism, the subjection of language to experience and to how the world presents itself to us, hence, as undistorted by language and by how experience is codified by language. In symbolism, language is the victor in the struggle between language and reality (and/or experience), whereas it is the vanquished party in the movement of the 1880s. As a result, the distrust of language made the poets and the novelists of the 1880s experiment with language and invent new words and neologisms they considered to do better justice to the experience of the world than existing language. The distance between language and reality should be reduced according to van Deyssel and his followers; this often led to the use of neologisms suggesting and effecting an absorption into language of the world itself, of its colours, of its materiality or, as the case might be, of its lightness and transitoriness. Literary writing became 'a painting with (new) words'. It's not so easy to say why the movement of the 1880 s opted for a track that was the exact opposite of symbolism. But part of the explanation certainly is that our national culture is painterly rather than literary: it privileges how we see and experience the world to what we may say about it. It is realist through and through. (Ankersmit and Menezes 2017, 250)

As we can see from the last phrase, some kind of 'realism of the senses' (but not of knowledge) is, for Ankersmit, behind what Huizinga called 'historical sensation' - and we might see the same kind of realism in Ankersmit's experiential enterprise. We can surely say, then, that Huizinga (like Ankersmit) was talking about something other than 'historical awareness' or 'historical imagination,' for example, since those are - just as historical representation - acts of association or of looking from without. In contrast, historical sensation involves seeing, feeling, touching and hearing 'from within' (through a contact with the past). It is 'a momentary flash in the minds of historians possessing an unusually acute sense of history' (Ankersmit 2012, 188). In this sense, Huizinga (in a 
passage Ankersmit quotes many times) explained that: 'This contact with the past, that is accompanied by the absolute conviction of complete authenticity and truth, can be provoked by a line from a chronicle, by an engraving, a few sounds from an old song. Huizinga observed that this is not 'an element that the author writing in the past deliberately put down in his work. It is 'behind' and not 'in' the book that the past has left us' (quoted in Ankersmit 2005, 120). This realism that relies on acts of dissociation instead association is thus completely different in kind.

The same performance of identification with past reality is what Ankersmit - following Huizinga - now calls historical experience. But, as he sought to make clear, this identification with reality is not 'a triumph of the self over reality but rather a 'pathos', a passive submission and complete receptivity to it' (Ankersmit 2005, 132). So, in the acts of association - like historical writing and historical representation - the historian has an active role to play; while in the moment of dissociation, he or she is passive. Hence, as Ankersmit goes on to explain, such

Sensation is momentary and has little or no duration; it is abrupt and cannot be predicted. It is accompanied by a sense of anxiety and of alienation: the direct experience or sensation of reality provokes a loss of the naturalness of even the most trivial objects. This explains why sensation is so enigmatic and why the right words seem to fail us for describing its content: experience here precedes language and the whole complex web of associations that are embedded in language. [...] Sensation effects a fissure in the temporal order so that the past and the present are momentarily united in a way that is familiar to us in the experience of 'déjà vu'. (Ankersmit 2005, 132)

This seems to be a description by someone who has actually had a historical experience or sensation - this flash of light coming from the past - and who is now returning to his fellows inside 'the cave of language' doing his best to convince them that ' $[\mathrm{i}] \mathrm{t}$ is possible. It happened to people like Huizinga, and it might happen to others; but I cannot say exactly how, either you have it or you don't; it is not repeatable or reproducible, otherwise it is not a sublime experience at all!' At this point, one might object that historians are not supposed to have such historical experiences to become historians, but, to be fair, we should remember that Ankersmit never claimed that to be the case. Historians are usually seen as historians when they provide a reliable account of a certain part of the past, following the procedures and employing the abilities in which they were trained. According to the wisdom of narrativist philosophy of history (on which Ankersmit relied in the earlier phase of his work), there is no escape from the confines of language. Hence, it seems clear that Ankersmit's account of experience is at odds with narrativism and the so-called linguistic turn, and, further, that he seems satisfied with this; we might even think that it was his aim from the beginning to make waves on the calm and peaceful waters of narrativism. 


\section{A'lost historical cause'?}

It seems fair to say that 'historical experience' brought more war than peace. Certainly, critical assessments like Peter Icke's Frank Ankersmit's Lost Historical Cause (2012) attempted to show that historical experience 'could never have given him the real history that he sought'. According to Icke, Ankersmit fails to recognize three important features of the relationship between language and experience: (a) First, 'that the past as an object of study is constituted only in its language of description' (Icke 2012, 104); hence, (b) that there is no experience outside of language, because only language could constitute experiences (or, repeating Rorty, language indeed goes all the way down); and (c) that there is no possibility of a decontextualized experience or an experience without subject or object, since (as he puts it elsewhere) 'experience is always contextualized within a language bound framework of understanding or 'realization' and that it therefore cannot be pure as required by Ankersmit's theory' (Icke 2014, 532).

So, in evaluating Ankersmit's excursion into the collective sublime via traumatic experiences (what he called 'the groanings of a civilization'), Icke's main conclusion is that Sublime Historical Experience would be better situated in the field of sociology and memory studies than in history - as the collective title of the series which the book appeared in in fact already suggests: 'Cultural Memory in the Present' (Icke 2012, 144). I will not play the philistine here and attempt to deny that the issue of memory, although not as explicitly addressed in Ankersmit's book, is in some way related to that of experience (especially to its collective kind). Indeed, Ankersmit recognized that 'the remembered past undoubtedly is a past that we 'experience' in one way or another' and, further, that 'memory gives us an experience or re-experience of the remembered past' (Ankersmit 2005, 5). On the other hand, in a more recent statement, Ankersmit noted that if one is to compare memory with history, then it is very important to respect the balance between the two:

There is a certain asymmetry between my memories and what I consider to be my history, and it is clear that history is the stronger and more important partner of the two. This conclusion may make us look with some suspicion at the present cult of memory, which may, in the end, result in a cult of the irrelevant. (Moskalewicz 2014, 558)

This makes perfectly clear that: (a) Ankersmit considers history a more important and stronger partner in his work than memory; (b) he does not denounce all talk of memory, but, at the same time, is suspicious of the present concentration on memory studies; and (c) he thinks that this focus may at times result in a praise of the insignificant. Icke, in turn, could contest this by saying that Ankersmit's Sublime Historical Experience is a good example of this 'cult of the irrelevant' and a 'lost historical cause' - and I would not entirely deny this either, because Ankersmit himself recognized (albeit for different reasons than Icke) that this touch of inutility is, in fact, one aspect of the book. Yet, for all this, I 
am not in favour of banishing sublime experience from the realm of history to that of memory in the manner of Icke. At the very least, this would require a discussion of the differences or the intertwining between history and memory, ${ }^{2}$ which is something that Icke in my view did not undertake.

With that said, I would like to make two remarks about Icke's account of Ankersmit's work - and admit to being intentionally selective with these. First, on reading Ankersmit, I - like Peter Icke, Ewa Domanska and Anton Froeyman - felt that sublime historical experience did not appear as something that is feasible for all historians, but instead for those belonging to elites only. Ankersmit's best example is that of Huizinga, who had a historical experience or sensation due to his profound knowledge of the past and his deep sensibilities as well as his quasi-poetic or artistic capacity to express a certain mood and/or feeling of the late Middle Ages, all of which resulted, as Ankersmit would put it, in a perfect union of form and content. In this sense, historical experience can be had, in Icke's words, only by a 'small number of appropriately gifted historians (connoisseurs)', so that 'such experiences, if taken seriously, are also exclusively confined to current elites who receive messages from former elites' (Icke 2012, 121). Domanska similarly criticized Ankersmit for his lack of attention to the concerns of the 'new humanities' with ethnic, postcolonial and gender studies, for example, suggesting that this makes Ankersmit's arguments philosophically abstract, elitist, logocentric and 'detached from historical practice' (Domanska 2009, 190). Finally, for Froeyman, one of the main limits of historical experience or sensation in Ankersmit lies in the fact that

It is a privilege of practicing historians who deal with the real material, such as the documents themselves, the materials and the witnesses, and it can never be transferred to the audience which reads their books. Therefore, historical sensation is an elitist notion, limited to the elite of practicing (professional) historians (Froeyman 2012, 409).

Having said this, I think it is of little help for an understanding of historical experience to follow Icke or Domanska in judging Ankersmit's work by imposing some transcendental criteria on it. For good or for worse (it depends on how one looks at this), Ankersmit never promises to tackle these themes in his book. Quite the contrary, he makes this very clear when he states that 'the kinds of issues to be dealt with in this book are ... useless and meaningless from the perspective of the practice of historical writing' (Ankersmit 2005, xvi). (Here one may diagnose a common habit among scholars: we are always evaluating academic works from the viewpoint of 'what they should have done', not from 'what they actually did').

Second, the relationship between Ankersmit and White appears as an obsession and overstatement in Icke's book. To an extent, and similarly based on Ankersmit's claims, I agree that the aim of Sublime Historical Experience is in part to challenge the Whitean way of speaking about history and historical writing. But it seems that Icke overemphasizes this in a very questionable 
manner, as a result of his obsession to prove Ankersmit's (made-up) fixation to overcome White - something that becomes the 'core of his explanation because he repeatedly alludes to it' (Zelenak 2014, 264). Let me illustrate this by narrating the book's story through the lens of this 'Whitean explanation':

(1) The 'Good Ankersmit' was in fact very good because he had a complex and original way of argumentation and because he developed the notion of 'Narrative Substances' - a remarkable notion, but only an expansion, a re-description or a re-working from a text that had already been written; an amplified and better version of Walsh's colligatory concepts; 'a kind of Metahistory plus or minus something' (Icke 2012, 121). All in all, he was pretty much 'defensible' at this point and while White was 'omnipresent' in his work. And, if he had stopped there, 'everything would (or could) have been fine' (Icke 2012, 157). In this sense, Jouni-Matti Kuukkanen well observed that 'the hero of Icke's book is Hayden White against whom much of the 'goodness' [and 'badness' (J.M.)] of Ankersmit is measured' (Kuukkanen 2015, 204n). The 'European White' is the alter ego of the 'Good Ankersmit'.

(2) However, in 'a moment of hesitation', Icke found that there might be some strange elements even in Ankersmit's narrative logic: some residues of foundationalism, an 'illusion of proof', a misrepresentation of White's work, amongst other problems. These less enjoyable parts of his work show that he was not so much like White, after all - he was not 'that good'. The curious thing is that the elements in Ankersmit's narrative logic that revealed his differences with White's narrativism - like his care for (some level of) truth, his refusal to confuse the narratio with 'mere storytelling', his concern about 'the best criterion for deciding upon the relative merits of individual narratios' (Ankersmit 1983, 227) - became the most regrettable ones according to Icke's assessment.

(3) But there's more. According to Icke, Ankersmit then entered into a period of transition. He became fatigued with being the 'European White', for that was not enough for him. He wanted to be more; he wanted (he needed) to be original! How could he get that? He prepared the stage for a grand finale, a final release from White. The route was well described in his interview with Ewa Domanska (1998): First, he said that narrative is an effective instrument 'for making sense of the world in which we live'; it is our way of changing reality (of the past) according to our desires and purposes. But, second, he also began to have his doubts about the current use and understanding of narrative, for it is a way of violating the past, of robbing the past of its own 'authenticity'. How can we preserve the authenticity of the past from a narrative's violence? Third, his answer: by reaching some different kind of 'contact with the past' that must be free from what we made of it. 
(4) This is how he became interested in and arrived at the notion of 'sublime historical experience', and that is how, in Icke's view, he completely 'lost his way'. He lost his path to 'history as we know it', the Whitean kind of history, when he decided to get rid of what he called 'linguistic transcendentalism' in exchange for a non-linguistic and non-historical, albeit claiming-to-be-historical, experience. Historical experience was his answer for getting 'back in touch' with the authenticity of the past without any kind of mediation. And that is complete nonsense, for there is no way we can get in touch with a past which is gone for good; there is no decontextualized experience. This completely contradicts 'White's condition of possibility for any sort of history at all' (Icke 2012, 143). So, the best solution is to rule it out from the academic scene.

Perhaps I oversimplified Icke's story here, and I hasten to add that it is not my intention to underestimate it. I simply do not wish to trace it further because this is not an assessment his book, but of Ankersmit's idea of historical experience. Again, I admit that White cannot be overlooked when it comes to understanding Ankersmit's work. At the same time, what you get from saying that he has been omnipresent, always in the back of Ankersmit's mind in everything of relevance (or irrelevance) during his whole intellectual career, is just a caricature that fails to appreciate the complexity of Ankersmit's oeuvre. Besides, why not then do the same with Leibniz ${ }^{3}$ or Danto ${ }^{4}$ They were (and still are) even more fundamental inspirations for (understanding) Ankersmit's work than White.

\section{Representation and experience}

Because Icke decided to see Ankersmit's intellectual journey as a journey from language to experience he could not, in my reading, focus sufficiently on the complexity of Ankersmit's development of the idea of 'historical representation' beyond this limited picture. In other words, it seems that narratio, narrative substances and historical interpretation can, for Icke, be seen as synonymous with that of historical representation. So, if one offers an account of Ankersmit's enterprise in Narrative Logic (as Icke does in his first chapter), then one might be excused for not paying much attention to what he made of the notion of historical representation afterwards, assuming that everything has remained unchanged since then. I do not agree with this (implicit) view, however.

On the one hand, it is not a mistake to associate 'narrative' with 'representation' when you have, for instance, the White of The Content of the Form and the 'early Ankersmit' in mind. White believed that representations of reality are dependent on and 'embodied in historical discourse' (White 1987, 24). The nature of representation here is attached to the nature of narrativity: representation of reality is what you get as the result a historical discourse that narrates. So, Icke's claim seems to be a retrieval of White's conviction of 'narrativity as a 
form of representation' rather than a proper understanding of Ankersmit's further development of the idea of representation. In Narrative Logic, Ankersmit interestingly used the expression 'narrative representation' (a conflation of the two expressions) to indicate what he then called 'narratio' - 'a linguistic entity essentially different from other coherent systems of sentences such as poems, novels, sermons, mathematical proofs and so on' (Ankersmit 1983, 22, emphasis mine). This came with a clear warning to his readers: 'whenever in this book the terms 'narratio' and 'narrative substance' are to be used, all associations with the belles-lettres and with a story-telling kind of historiography should be avoided' (Ankersmit 1983, 16). Moreover, in History and Tropology, in the same way that White said that representations are embodied in historical discourse, Ankersmit defined a 'narrative substance' as the set of statements 'that together embody the representation of the past that is proposed in the historical narrative in question' (Ankersmit 1994, 113, 114). In other words, he said that 'narrative substances are the representation of historical reality' (Ankersmit 1994, 115, emphasis mine). In sum, the historian gives (or 'imposes', in a Whitean manner) a meaning to the past through the historical representation. No representation, no meaning and, thus, no past. So far so good, and I agree that this is the 'zero ground' of his theory.

On the other hand, in Ankersmit's writings from History and Tropology onwards - or even before, if we consider that he wrote one of the essays of the book, on historical representation, already in 1988 - the spotlight began to deviate from narrative towards the nature of historical representation. When he wrote the book Historical Representation (2001) he was interested in the question of how to relate the historical text with (aspects of) reality, or in the relation between representation and its represented. He was convinced by then that literary theory could never give a proper answer to that, for 'no compartment of literary theory addresses the problem of the epistemological gap between language and the world'. The conclusion being that literary theory is 'useless' as a historical theory, for 'it has not said and could not possibly have anything of interest to say about the issue of how the historian succeeds in representing the past' (Ankersmit 2001, 74).

This same critique was directed, for obvious reasons, at White's historical theory some ten years later in the preface to Ankersmit's 'Brazilian book': 'White's theory of history is immensely valuable for the historian of historical writing - but it will yield no answer to the question of how best to account for the past' (Ankersmit 2016, 21). My point here is that there was an important 'turn' in Ankersmit's theory concerning historical representation in his later writings when compared with Narrative Logic. If, before, representation was a mere 'linguistic entity', now, the reverse might be true. In his words: 'from the present prospective $[s i c]$, (narrative) language is just one more variant of the representation of reality' (Ankersmit 2001, 88). This reversal strategy consists in investigating the nature of historical representation in order to clarify the 
narrativist use of language and not the contrary. Which means, as he goes on to say, that 'language here is the dependent variable, so to speak, instead of being the origin and source of all true philosophical insight - as ordinarily has been the case in most twentieth-century philosophy' (Ankersmit 2001, 88; emphasis mine). At this point, one might already notice that the parallel between this statement and those related to his 'turn to experience' is very clear. Representation is at this point assumed to be the 'lord and master', whereas language (be it narrative or not) must be the obedient servant; much in the same fashion as the relation between language and experience, in which 'language runs after experience in a forever vain effort to keep up with it' (Ankersmit 2012, 208).

Let me complete my argument with one last example. To remove the confusion between the work of 'narrativist' theorists and Ankersmit (especially in his later phase), he explained in an interview that

My first book was influenced by the idea that a historical account is a narrative of the past, the idea that had also inspired Hayden White and Louis Mink and others. But I have always had a certain problem with people like White and Mink in the sense that they said "Well, if historical accounts are narrative, then you should also make use of literary theory in order to investigate it, for literary theory is the theory that deals with complex texts and that may give you the instruments for dealing with narrative." I have always felt that since a historical narrative attempts to do justice to the past in a sense that you could not possibly say about a novel, the historian finds himself in a fundamentally different situation. And this is why I wanted to cut through all ties with literary theory and why, without changing conceptually or theoretically, I preferred to replace the term narrative by representation. Representation is a neutral term. I think it also quite adequately describes what a historian does - he gives a representation of the past in the sense of making the past present again. That is why we need historical writing. A representation is not necessarily a narrative; you have the so called cross-sectional studies, the famous example being Jacob Burckhardt's Die Cultur der Renaissance in Italien or Huizinga's The waning of the middle ages or Braudel's on the Mediterranean world. They do not tell a story, they do not give us a narrative with a certain beginning, middle and end, but they are historical works representing the past. Moreover, I soon decided to exploit the aestheticist connotations of the term "representation"; so my enterprise also took on the features of an exploration of the rationality of aesthetic representation.

(Molven 2007)

It is clear from this quote that: (a) Ankersmit's comprehension of historical representation has changed since his first book, following his shifts in interests; (b) at the time that he decided to resolutely replace the term 'narrative' with 'representation', he was trying to avoid the conflation of the latter with literary theory's comprehension of historical narrative as a variant of the novel; (c) historical representation became for him more than just 'a proposal' (basically in narrative form) for how to view the past (also in the form of a 'text'); now, it also means - thanks to Danto's view regarding the 'theory of substitution' - making the absent past present again, which is, by the way, how representation can be 
related to Ankersmit's understanding of 'presence', presence being 'part of the meaning' of representation (Ankersmit 2006, 328); (d) finally, it is another way of leaving epistemology (and linguistic transcendentalism) behind in favour of aesthetics as the study of the forms of representation.

Needless to say, this is just a schematic overview of how historical representation evolved through his oeuvre and became, together with historical experience, the centre of Ankersmit's interests. For further analysis of the recent changes and developments in Ankersmit's theory of representation, one should start by studying his last book Meaning, Truth and Reference in Historical Representation (2012). A book that Icke could not foresee of course, but in which Ankersmit certainly reveals that he did not move 'from language to experience.' Instead, he has absorbed experience within his account of language, representation, and so on, as a supplement rather than a substitute to all that he wrote before. Ankersmit has claimed many times, as a philosopher of history, to also be a philosopher of language, and I think he still is.

Now, returning to the issue of experience, my personal view is that it can be viewed as analogous to religious experience, despite being secular (or 'historical'). This is because, much like religious experience, it has the characteristic of being beyond proof and cannot be translated into language without causing damage to the experience itself. In other words, either this experience is mute or it is not a sublime experience at all. Ankersmit's description of Huizinga's notion of 'sensation' exposes the common ground between historical and religious experience, that is, the impossibility of finding the right words to describe the content of this experience (or to translate it into language or discourse). While this is a most regrettable feature of the Ankersmitean kind of experience - according to the 'acceptable' standards of narrativist philosophy and historiography in general - it should be the most welcomed feature of the religious one.

I would say that not only history but also religion (as much as it is a form of discourse) works within the categories of association and dissociation, or (even more) of mediation (the role of priests, might be an example) and what is immediate (that is, the direct contact between the pious or the believers and their God). In a broad sense, 'experiencing God' precedes the talk about God. And religion, as we know, is all about talking, domesticating, institutionalizing and ritualizing the so-called 'religious experience' of the pious; one might even say that religion is the outcome of the sum of experience and organization. But, an organized experience might still be an experience? Perhaps Ankersmit would say: 'Well, yes, but a very poor kind of experience'. After all, the 'richer' form of experience (sublime experience) is irretrievable. Let me offer one more example.

In his amusing book, The Great Divorce, C. S. Lewis tells the story of a group of passengers who suddenly find themselves on a bus excursion from hell to the foothills of heaven. These people are revealed to be 'ghosts' who, in heaven, meet some 'shiny and happy people', men and woman, called 'spirits'. And these spirits offer to assist the ghosts from hell during the journey towards 
the mountains and the sunrise of heaven, ir order to show the kind of eternal life they could enjoy if they repent and turn to God. One of the ghosts (who was a well-known painter in his earthly life), amazed by the astonishing sights of that exceptional place, said:

'I should like to paint this!'.

Then, one of the spirits warned him: 'I shouldn't bother about that just at present if I were you'. But the ghost insisted: 'Look here; isn't one going to be allowed to go on painting?'

'Looking comes first', replied the spirit.

'But I've had my look. I've seen just what I want to do. God! I wish I had thought of bringing my things with me!'

The Spirit shook his head, scattering light from his hair as he did so. 'That sort of thing is no good here', he said.

'What do you mean?', said the Ghost.

'When you painted on earth - at least in your earlier days - It was because you caught glimpses of Heaven in the earthly landscape. The success of your painting was that it enabled others to see the glimpses too. But here you are having the thing itself. It is from here that the messages came. There is no good telling us about this country, for we see it already'. (Lewis 1984, 79, my adaptation)

Like the spirit who tells the ghost that there is no point in painting those heavenly landscapes - because he already has 'the thing in itself' - Ankersmit presented a double reminder to practitioners of history (and also of religion, if I may): (1) First, regarding what lies beyond acts of association and representation of reality: the 'transcendent' and unknown world of the sublime, to which one may have 'access' if one is sensitive enough to this kind of experience, as was Huizinga; (2) second, regarding the fact that there is no use in trying to express the content of this experience in language, for it cannot be 'contained' in it, except through those 'glimpses of Heaven in the earthly landscape' (what we might call historical, theological or philosophical 'talent' or 'insight'), enabling others to see something beautiful about 'the thing', although not 'the thing in itself. You can be inspired and transformed by the view, but cannot contain it. To paraphrase Ankersmit $(2012,202)$, it is the 'moods and feelings' of experience that have us and not the contrary.

\section{Experience as the suspension of language}

In my view, historical experience is of a highly personal kind, and nobody can say with certainty whether or not it happens. After all, if someone claims that it has happened, who would dare to say that it did not? Thus historical experience involves a state of being beyond the realm of subjectivity and objectivity. The sensation that it causes is 'felt' by the person directly, influencing his or her representation (not of the experience but by the experience). So, for Ankersmit, historical experience is self-sufficient in the sense that it lies in a realm 'after or beyond all historical writing', having 'no affinity with beginnings, foundations, 
first principles, and so on' and historians may now consider the possibility of sometimes breaking from 'the prisonhouse of representation' in order to be in contact with the lost past (Ankersmit 2005, 277). While this satisfies Ankersmit's desire to escape, by a suspension of context and language, from the crisis of language and representation, it does not deny that there is still a place for representation, not in experience but after. In this sense, I think Froeyman is right when he says that:

Sublime historical experience is the starting point of any inquiry into history, and historical writing or representation is its result. So, although the two factors of the equation need each other (without historical experience, there would be no historical writing, and without historical writing, we would never become conscious of the existence of historical experience), there is very little mutual influence: (sublime) historical experience is one thing, and historical representation is quite another. (Froeyman 2015, 166, 167)

Ankersmit's favourite example of this rather paradoxical relation between experience and representation is, again, Huizinga. As we saw, the gist of Sublime Historical Experience is that experience is what lies beyond the realm of language. In Huizinga's case, Ankersmit claimed that it was possible, thanks to a profound sensibility and historical knowledge, for Huizinga to catch glimpses of the 'historical sensation' he claimed to have had during his visit to the Van Eyck exposition in 1902, and to express these glimpses with exceptional talent in The Waning of the Middle Ages. Nevertheless, regardless of the unprecedented ability he had to paint his experience with words (as Ankersmit would put it), Huizinga still had to deal with the historian's usual question of how to give the best possible account of that part of the past. How could he succeed in this down-to-earth task? According to Rik Peters:

From a rhetorical point of view, Huizinga's attempt is not effective because his readers have the same experiences he had, let alone the experiences that Jan van Eyck had. Instead, it is effective because they are able to take Huizinga's words, or more precisely, his narrative organization of words, as a narrative of their own. It is this narrative that pulls readers into an experience of a past which is completely foreign to the present. (Peters 2016, 251)

This means that although the Ankersmitean historical experience may, in a somewhat 'mystical' sense, precede representation, it still needs representation - as Ankersmit admitted in another interview - 'in order to become aware of what you inevitably lose with it' (Moskalewicz 2007, 261). In this sense, historical experience is born in paradox: it is a paradoxical enterprise from a historical point of view, and cannot be understood if one takes its complex and paradoxical nature for granted. The most conspicuous of Ankersmit's paradoxes thus needs to be understood too: he is looking for a language to undo language. A language to undo language is no less paradoxical than someone using a gun as an instrument for peace. In one way or another, 'the moral' of Sublime Historical Experience may be that in the philosophy of history we will always 
need language, even when conveying an attempt to escape from it. Ankersmit does not propose some throwback to an epistemological stage (to knowledge as a mirror), as presented and criticized by Rorty and even Ankersmit in the past. Instead, my impression is that he turned to experience precisely because he has too much respect for the achievements of the linguistic turn. In other words, in granting (to the historian) the possibility of a renewed contact with the past via experience, Ankersmit is implicitly endorsing one of the corollaries of the linguistic turn in the philosophy of history while indicating that there is an almost insurmountable cleavage between the historical text and the historical past. In this sense, the attempt to go beyond Rorty and his 'linguistic transcendentalism' through the path of sublime experience also means recognizing (together with Rorty) the contingency of language.

Therefore, my final comment focuses on something that Ankersmit states at the beginning of chapter 7 of Sublime Historical Experience: 'My account of historical experience requires us to suspend the transcendental, theoretical, linguistic, tropological, or semiotic schemata that we are tempted to project on the past and in terms of which 'theorists' have always formulated their prescriptions to historians' (Ankersmit 2005, 263, emphasis mine). One may note that Ankersmit's tone here is slightly different from the position held at the beginning of the book, about 'doing away' with all those 'products' of the linguistic turn, but I think that what he is saying here does more justice to the role of Sublime Historical Experience in his intellectual journey. It does not involve leaving language or representation behind. When Ankersmit talks about experience he is not moving from language (or representation) at all, but speaking about the need of a suspension of language in order for historical experience to shine. I share Froeyman's view that it is misleading to take 'Ankersmit's account of historical experience to be competing with his earlier notions of historical representation and narrative substances'. For, as Froeyman explains: 'When Ankersmit talks about historical experience, he is talking about the past as it constitutes us. When he talks about historical representation, he is referring to historical reality as we constitute it, which is something completely different' (Froeyman 2012, 397).

Besides, Sublime Historical Experience should, in my view, be seen as a totally different book to everything that Ankersmit has written before; it is his most personal, dark, moving and introspective book (with some touches of an autobiography), in which we see his romantic side speaking loud and clear, longing to reconnect with the 'paradise lost' of the past. In this sense, in spite of praising Icke's book, Kalle Pihlainen notes that Icke fails to value and respect how 'the lost Ankersmit' is enchanted by this new world: 'he is persuaded by a world that feels to be full of mystery. And it is this experience of the world as mysterious that leads him down the path he takes' (Pihlainen 2015, 315). Pihlainen also observes that, 'in spite of the difficulties involved' - and he is talking of the difficulties pointed out by Icke in his book, for example, about 
experience not being 'historical' or indeed an 'experience' at all, but instead an 'existential sensation' (Icke 2012,3) - 'Ankersmit's insistence on 'experience' is not of course accidental'. For,

What his choice of the word experience does do - and in his context quite fittingly - is emphasize the presence of history (not the past) or at least historicity in everyday lived experience. And in this very different meaning of 'historical', the historicity of (many if not all) people's negotiations with the world, 'historical experience' as a general idea makes sense and cannot be overlooked. (Pihlainen 2015, 313)

Accordingly, since the notion of historical experience requires less a prior action on the part of the historian and more the banality of 'waiting' (perhaps the little bird of experience will come, without any artificial prompting, to rest on our shoulders), and since it is 'useless' from a practical point of view and cannot be taken as a decisive argument in a historical debate, should Ankersmit surrender to the temptation of presenting it as a philosophical programme (as with his narrative logic and his representationalism, for example)? I do not think so. If there is something like historical experience, it involves aesthetic pleasure and inspiration only. After all, one could not prescribe or encourage a historical experience in the way that one can endorse historiography as a representational activity (in the Ankersmitean sense). But, for this very reason, Ankersmit's intellectual journey, at least as I see it, does not culminate in experience, but absorbs it without neglecting the fundamental place of historical representation. For Ankersmit, one would not be the same without the other.

\section{Notes}

1. Here is one of Ankersmit's comments on this interaction between historicism and experience: 'If we may infer that Ranke would have rejected historical experience from the fact that he never raised the issue in his numerous writings. On the other hand, it is admittedly true that Ranke asked the impossible of the historian when demanding with all the considerable rhetorical power available to him that he should 'wipe himself out.' Nevertheless, the very idea of the historian 'wiping himself out' - so that only the past itself can speak through his mouth - is not that far removed from the direct and immediate contact with the past promised by historical experience. So, perhaps Ranke was not so hostile to historical experience after all. To sum up, I don't think there exists a necessary link between historicism and the notion of historical experience; nevertheless, historicists are probably more amenable to the notion than philosophers of history of other denominations.' (Ankersmit and Menezes 2017, 273).

2. For further consideration of this topic, see, for example, Megill 2007, 17-59; and (more connected to the present discussion) Pihlainen 2014, 103-115.

3. It is true that Icke comments on the way that Leibnizian monadology influenced Ankersmit's notion of 'narrative substances' but only in passing (see Icke 2012, 46-48). For a more detailed account of Ankersmit's Leibnizianism, see Ankersmit and Tamm (2016, 491-511) and Fairbrother (2017, 59-82). 
4. As to Danto, Ankersmit notes his importance in the preface of Sublime Historical Experience: 'My debt to Arthur Danto is of a different kind: I came to the notion of historical experience by means of that of (historical) representation. And is there anything worth knowing about representation that does not have its antecedents in his oeuvre - an oeuvre that is unique in its combination of penetration and elegance?' (Ankersmit 2005, xvii).

\section{Acknowledgements}

Special thanks to Kalle Pihlainen for his remarkable work with the language of this article's first draft. I also benefited from helpful comments made by Frank Ankersmit, Eugen Zelenak, Zoltan Boldizsar Simon, Peter P. Icke and the two anonymous reviewers. This does not mean, however, that they agree with the views expressed here. Some small pieces of this paper were previously published in a 'short communication' on the Arts and Humanities $O A J(1: 3,2017)$ and I thank the editors for allowing me to reuse them here.

\section{Disclosure statement}

No potential conflict of interest was reported by the author.

\section{Funding}

This work was funded by CAPES-PDSE, Brazil [grant number 88881.134902/2016-01].

\section{Notes on contributor}

Jonathan Menezes is an associate professor of philosophy and history at South American Theological Faculty, Londrina, Brazil, and a PhD candidate of the Department of History at Sao Paulo State University, Brazil. He is working on his dissertation about Frank Ankersmit's intellectual journey, named 'Frank Ankersmit: The Metamorphosis of Historicism', which will be defended in the late 2018. Jonathan's work can be read in the journals Estudos Historicos, Antiteses, Journal of the Philosophy of History and this journal.

\section{References}

Ankersmit, Frank. 1983. Narrative Logic: The Semantics of Historian's Language. The Hague: Martinus Nijhoff.

Ankersmit, Frank. 1994. History and Tropology: The Rise and Fall of the Metaphor. Berkeley: University of California Press.

Ankersmit, Frank. 2001. Historical Representation. Stanford, CA: Stanford University Press.

Ankersmit, Frank. 2005. Sublime Historical Experience. Stanford, CA: Stanford University Press.

Ankersmit, Frank. 2006. "Presence and Myth." History and Theory 45 (3): 328-226. 
Ankersmit, Frank. 2007. "Danto and the Tragedy of Human Existence”. In Action, Art, History: Engagements with Arthur C. Danto, edited by Daniel Herwitz and Michael Kelly, 175-197. New York: Columbia University Press.

Ankersmit, Frank. 2012. Meaning, Truth and Reference in Historical Representation. New York: Cornell University Press.

Ankersmit, Frank. 2016. A Escrita da História: A Natureza da Representação Histórica [The Writing of History: The Nature of Historical Representation]. 2nd ed. Londrina: Eduel.

Ankersmit, Frank. Forthcoming. "Individuele en Collectieve Nostalgie." Groniek.

Ankersmit, Frank, and Jonathan Menezes. 2017. "Historical Experience Interrogated: A Conversation." Journal of the Philosophy of History 11 (2): 247-273.

Ankersmit, Frank, and Marek Tamm. 2016. "Leibnizian Philosophy of History: A Conversation." Rethinking History 20 (4): 491-511.

Danto, Arthur. 1981. The Transfiguration of the Commonplace: A Philosophy of Art. Cambridge: Harvard University Press.

Domanska, Ewa. 1998. “Franklin R. Ankersmit.” In Encounters: Philosophy of History After Postmodernism. Charlottesville: University Press of Virginia.

Domanska, Ewa. 2009. "Frank Ankersmit: From narrative to experience." Rethinking History 13 (2): 175-195.

Fairbrother, Daniel. 2017. "Leibniz and the Philosophical Criticism of Historiography." Journal of the Philosophy of History 11 (1): 59-82.

Froeyman, Anton. 2012. "Frank Ankersmit and Eelco Runia: The Presence and the Otherness of the Past." Rethinking History 16 (3): 393-415.

Froeyman, Anton. 2015. "Never the Twain Shall Meet? How Narrativism and Experience can be Reconciled by Dialogical Ethics." History and Theory 54 (2): 162-177.

Icke, Peter. 2012. Frank Ankersmit's Lost Historical Cause: A Journey from Language to Experience. London: Routledge.

Icke, Peter. 2014. “Author's Response to Eugen Zelenak's Review of Frank Ankersmit's Lost Historical Cause." Organon F 21 (4): 531-533.

Ireland, Craig. 2004. The Subaltern Appeal to Experience: Self-identity, Late Modernity, and the Politics of Immediacy. Montreal: McGill-Quenn's University Press.

Kellner, Hans. 2006. “Ankersmit’s Proposal: Let's Keep in Touch.” Clio 36 (1): 85-86.

Kuukkanen, Jouni-Matti. 2015. Postnarrativist Philosophy of Historiography. London: Palgrave Macmillan.

Lewis, C. S. 1984. The Great Divorce. New York: Collier Books.

Megill, Allan. 2007. Historical Knowledge, Historical Error. Chicago, IL: The University of Chicago Press.

Mink, Louis O. 1970. "History and Fiction as Modes of Comprehension." New Literary History 1 (3): 541-558.

Molven, Frode. 2007. "A Proposal for How to Look at the Past: Interview with Frank Ankersmit”. Accessed November 20, 2017. http://www.culturahistorica.es/ankersmit/ interview_Frank_Ankersmit.pdf

Moskalewicz, Marcin. 2007. "Sublime Experience and Politics: Interview with Professor Frank Ankersmit." Rethinking History 11 (2): 251-274.

Moskalewicz, Marcin. 2014. "The Old Nietzschean Question Raised Again: How Much Past do We Need for Having a Healthy Life?" Rethinking History 18 (4): 556-568.

Peters, Rik. 2016. "Calliope's Ascent: Defragmenting Philosophy of History by Rhetoric." Rethinking History 20 (2): 235-258.

Pihlainen, Kalle. 2014. "The Eternal Return of Reality: On Constructivism and Current Historical Desires.” Storia della Storiografia 65 (1): 103-115.

Pihlainen, Kalle. 2015. “The View from the Fence." Rethinking History 19 (2): 310-321. 
White, Hayden. 1987. The Content of the Form: Narrative Discourse and Historical Representation. Baltimore, MD: Johns Hopkins University Press.

Zelenak, Eugen. 2014. “Peter P. Icke’s Frank Ankersmit Lost's Historical Cause." Organon F 21 (2): 261-279. 